\title{
TWO WORKS OF THE NEUE MUSIK COMPOSED ON THE LANGUAGES OF ANCIENT CULTURES
}

\author{
Jarmila Dou bravová (Praha)
}

The wide-spread world interest in the results of archaeological research, typical for the second half of the present century, has become apparent not only in a number of captivating publications translated into various languages, ${ }^{1}$ but also in the interest of the artists and theoreticians of art. In the work of the artists it was demonstrated by the quotations of the achievements of the ancient and extra-European cultures, or by the analytical taking over of some of their principles (for example, scales); in the theoretical works on art, it was instrumental, besides other influences, in abolishing their untenable narrow European centrism. This interest also probably played an important part in the development of one of the youngest branches of musicology, viz. the iconography.

The interest in the ancient and extra-European cultures has appeared with particular intensity in the Neue Musik. It was close to its international character and range, but above all to its artistic goals. The creation of an international musical language naturally aimed at the exploitation of the entire known cultural development of mankind. The facility of communication given by the progress of the communication media (including the large gramophone industry) and the relative accessibility of information not only supported an exchange of artistic experiences, but also created a period climate for the perception and reception of the new type of music. ${ }^{2}$

The ideal of the Metamusik, formulated as the program of the new art in the early seventies, ${ }^{3}$ eventually gave a designation to various

1 C. W. Ceram: Oživená minulost (A Picture History of Archaeology), Praha 1971; S. N. Kramer: Mytologie starověku (Mythology of the Ancient World), Praha 1977; Umění světa. Starověké kultury Předního Východu (Landmarks of the World's Art. The Ancient World), Artia 1971; B. Brent: Zlatý vêk lidstva (Von Schanidar bis Akkad), Praha 1973, etc.

2 Musik der sechziger Jahre. Darmstadt 1972.

3 Metamusik Festival in NG Berlin, Melos 1974, 12, 755-8. 
endeavours and types and kinds of creative work. The idea of connecting the art of all periods and cultures, which appeared in various forms in the synthetic attempts of the past centuries (classicism of the $18^{\text {th }}$ century, romanticism, particularly the Gesamtkunstwerk of the $19^{\text {th }}$ century, surrealism of the first half of the $20^{\text {th }}$ century, etc.) thus acquired a new image and name. The variety of styles of the Neue Musik yielded wide possibilities for applying manifestations orientated more analytically or more synthetically. 4

These trends have appeared outstandingly in the compositions on the languages of the ancient cultures, "Lamentations over the ruin of the city of Ur « by Luboš Fišer, and „Caccia barbara" by Jakob Jež. With both the authors the origin of the composition was conditioned by the general orientation of their work.

Luboš Fišer (born in 1935) completed Fifteen sheets for orchestra according to Dürer's Apocalypse in 1964. They became the first part of a triptych, whose second part are the Caprichos for two choruses according to Goya.(1966) and the third part, the Requiem (1968). The synthesis of the up to date musical principles (six-tone mode, aleatorics in metre and rhythm, emphasis on the colour qualities of the sound, importance of visual stimuli), together with thematic work and traditional musical form, ensured a high degree of originality, appreciated by international awards, to this and other works of the author, as well as a powerful response of the public. ${ }^{5}$

The progress of Jakob Jež (born in 1928) also developed in a synthesis of the up to date stimuli (linearity, exploitation of melodicrhythmic models, pure sound formation of musical structure, use of the principles of moment form) combined with the Slovenian vocal tradition. ${ }^{6}$ Do fraig amors (1968), a cantata for two mixed choruses, mandolin, lute, guitar and percussion, on the texts of the minnesänger Oswald von Wolkenstein, confirmed that here was an author with whom the stimuli of the Neue Musik found an original transformation: vocality, aphorismic character, feeling for detail and expressive lyricism; these were the features which developed in his further works of which the following are mentioned: Jacobi Galli disticha for piano, cymbal, triangle and lute (1970); Pogled narave (View of nature) on Krleža's Ballads of Petrica Kerempuh for soprano (temple blocks), mezzosoprano (claves), clarinet (cow bells) and corno (ratchet), from 1973;

4 See Note 2, and further: J. Doubravová: Sprache in der tschechischen Neuen Musik. Muzikološki zbornik, 1977, 77-83.

5 MGG, Bd. 16, Supplement E-Z. 297-8; J. Doubravová: Time of Structure and Structure of Time (Čas struktury a struktura času), Hudební věda 1976, 2, 128-146; M. Kuna: Na slovo o hudbě s Lubošem Fišerem (A Word about Music with Luboš Fišer), Hudební rozhledy 1980, 9, 418-20.

6 Muzička enciklopedija. L-Z. Zagreb 1963; 853; A. Rijavec: Slovenska glasbena dela. Ljubljana 1979, 101-06; I. Petrić: Soudobá slovinská hudba (Contemporary Slovenian Music), Hudební rozhledy 1965, 5, 212-13. 
and Pogled zvezd (View of stars) for three female voices, mixed chorus, male octet and orchestra, from 1974.

Both the authors have in common, besides the new sensualism, the vocal dramatic character and their interest in ancient texts. L. Fišer wrote Istanu for a reciter, alto flute and four percussive instruments on Hittite texts (first performance in Munich in 1979); J. Jež composed besides his earlier mentioned cantata on Oswald von Wolkenstein also the Odsevi Hajamovih stihov (Reflections on Omar Khayyam's poetry) for soprano and chamber ensemble (1966-67).

The Lamentations over the ruin of the city of Ur for soprano, baritone, three soloists-reciters, mixed chorus, children's chorus and mixed reciting chorus, seven timpani and seven bells, were composed between 1969 and 1970. The Caccia barbara for vocal quintet was composed on the order of the Cologne ensemble Collegium vocale in 1979. Both these works will be analyzed from the recordings: L. Fišer - Contemporary choral works, Panton 1972, 110298 stereo H; J. Jež - Collegium vocale, recording from the festival at Radenci in 1979.

In both the analyzed compositions the Sumerian language is used, in Jež's work also Hittite and Maya words. The Sumerian language belongs to the group of the so called agglutinative languages; it has nothing in common with the Semitic languages (flexis). In spite of all possible efforts no affinity could be established with any known languages. ${ }^{7}$ The selection of these languages made it possible for both the composers to effect a sound seizure of the text, above all to exploit the exotic sound of unknown words together with a maximum emphasis on the expression. L. Fišer proceeded rather synthetically so that he used the individual verses as units. The structure itself of the Sumerian poetry with its frequent repetitions and verse parallelism enabled him to emphasize similar qualities by musical structure. J. Jež used five words of each of the three languages and from them symbolically created three scenes: before the hunt, the hunt, and after the hunt. He conceived the individual words analytically and dissolved them into speech-sound groupings. He utilized the contradictory qualities of vowels and consonants, various qualities of consonants and various methods of the formation of sound by human voice (glissando, whispering, blowing, guffaw, etc.).

The Lamentations over the ruin of the city of Ur is among the most preserved relics of their kind. The sumerologists note that this was a frequently used genre and they enumerate other works of this type (Lamentations over the fall of the city of Agade, Lamentations over the ruin of the city of Nippur, etc.). ${ }^{8} \mathrm{~L}$. Fišer himself declared about

7 L. Matouš: Nářek nad zkázou města Ur (Lamentations over the Ruin of the City of Ur), Praha 1953. Foreword.

8 J. Klíma: Společnost a kultura starověké Mezopotamie (Society and Culture of Ancient Mesopotamia), Praha, 1962. 
his composition: ${ }^{9}$ "The Sumerian text, the Lamentations over the ruin of the city of Ur captivated me not only by the poetic value of its verses, but above all by the absolute addressness and urgency, by the direct expression of distress and horror of destruction and by the maximum exerted effort to save mankind ... For these reasons I directed all the elements and means of the composition to the idea of warning «.

The sound material of L. Fišer's composition ${ }^{10}$ consists of two semitone tetrachords in tritone relation, solo voices, choruses, timpani, bells and Sumerian text. Thematically, first of all both the tetrachords are utilized, in solo song and choral structure. While in both the solo voices their melodious character is conspicuous ( $b, b$ '), in the choral structure they appear as a fine aleatoric undulation of high pitches $\left(a, a^{\prime}\right)$ or in the form of a cluster $\left(x^{a}\right)$. Thematized are also the recitation of the responsorial type (c, d') and the exploitation of the instruments and the recitation of the soloists $\left(x^{1}, d\right)$. The composition reaches its summit with a large instrumental intermezzo (drum-roll of timpani) before a dramatic rest and the adjoining concluding part $\left(a, b, x^{a}, x^{2}\right)$. The whole of the composition is sharply contrasting, the individual parts are connected by a "cut", the overall four-part form

$$
x^{1} a b b^{\prime} y / c a^{1} d / a^{\prime} d_{z}^{\prime} y^{\prime} / a^{1} b^{\prime} x^{a} x^{2}
$$

is closed in principle by the quasi-repetition of the concluding part. Thematically, though, it remains open. The meaning palet of the composition contains besides lamentations $\left(a, b, b^{\prime}\right)$, prayers $\left(a^{1}\right)$, an irate and embittered challenge (d, $\left.d^{\prime}\right)$, an exclamation of horror $\left(x^{a}\right)$; among the most impressive moments is the use of children's voices in the recitation (c), where they respond to the male voice of the fore-singer, and the concluding children's exclamation: "Ama!" into the void $\left(x^{2}\right)$. Basically onomatopoetically are used the timpani and the bells: their compository character is gradating, but from the point of view of the meaning structure they symbolize the destructive forces of fate (storm,

9 In 1980 at the National Theatre (Smetana Theatre scene) the first performance was given of three ballets by contemporary composers, L. Fišer, L. Zeljenka and V. Kučera, under the common title of »Time of Man«. At this occasion the authors were invited to give their ideas concerning their works for the theatre program.

10 In the analyses of the works of the Neue Musik there always are alternative explanations possible, at least in some components (for example, the layout of the form). The analyser, however, as a verbal interpreter, undoubtedly has the right to choose the most adequate possibilities from the point of view of his method. The graphic representation should assist the orientation of the reader; the courses correspond to the subjective analysis of the general impression and graphic representation of the detailed development of the individual parts from the point of view of metamorphoses of the musical structure (orchestration, density, compository type) and dynamics. 
deluge), which are expressed by the text. A very acute meaning is engendered also by the ten seconds' rest after a gradating drum-roll (y') of the timpani.

L. Fišer creates a musical-dramatic abbreviation of the situation, a musical-dramatic scene in his composition. Its extraordinary appeal, raised to a high power, appeared in the already mentioned scenic arrangement (see Note No. 9) produced by P. Weigl; here, of course, the work was adjusted so that the compactness of the musical-dramatic abbreviation would not be in conflict with the scenic time needed to explain the plot.

J. Jež's work has a diametrically different character from the point of view of composition. The author wrote about his work that by selecting words he could represent "etwas Elementares, also keine Glasur oder 'Kultur' des im Leben sonst Gültigen. Nur extreme Not ... Für Absicht dieser extremen Not ist auch der szenische Teil benützt. Zuerst neben 3 Männer (Stimmen) auch 2 Frauen (Stimmen) sind und alle müssen und wollen jagen, bzw. auch schießen. Nach der wirklichen Szene des Schießens mit Jagdpfeilen wollen die Männer wieder schießen, aber beide Frauen wollen nicht mehr die Pfeile geben. Sie rufen nur um zu spielen". The composition is highly contrasting, but not thematically, its parts follow each other epically or they pass one into the other; the work has not a compact structure even if it has a closed form and a relatively long coda, and its overall character is lyrical and ballad-like. The author exploits the contrast between the recitation and singing (5), melodics and rhythm, sound of "instruments" which deliver the melodic-rhythmic model $(11,13)$, supplement the voices in the hunting scene (9) or form the punctuation (4). The starting unit in the melodic and rhythmic model, corresponding to the word, which the composer repeats and divides, transforms, augments. The peaks of the composition, musically bipartite in principle, are formed by a dense structure in which the voices take part (parts 6, 7, 8 and 9, 10); the manifold vocal structure oscillates between polyphony and heterophony. The acutest contrasts are conditioned by the exploitation of various qualities of the speech sounds (for example, of the sibilants or of special speech-sound connections: the Mayan word "trzul" - dog is divided so that the sharp "tr" . . is followed by the whispered "zul"), etc. In contrast to L. Fišer's basically sonata principle of thematic contrast stands Jež's basically rondo principle of change. This appears outstandingly in the introduction, where the male voice in a low pitch alternates with the meaning-bearing element of "blowing" (sound-wise: murmur, composition-wise: punctuation), as well as in the conclusion: in the extensive coda a tune of female voices, anticipated by the "instruments", alternates with male singing. In the conclusion again the punctuation element of the introduction (blowing) is used and the entire composition fades away in some sort of expiration. In the whole of the composition, speech-sounds are much prominent (such as, in part 3 of 


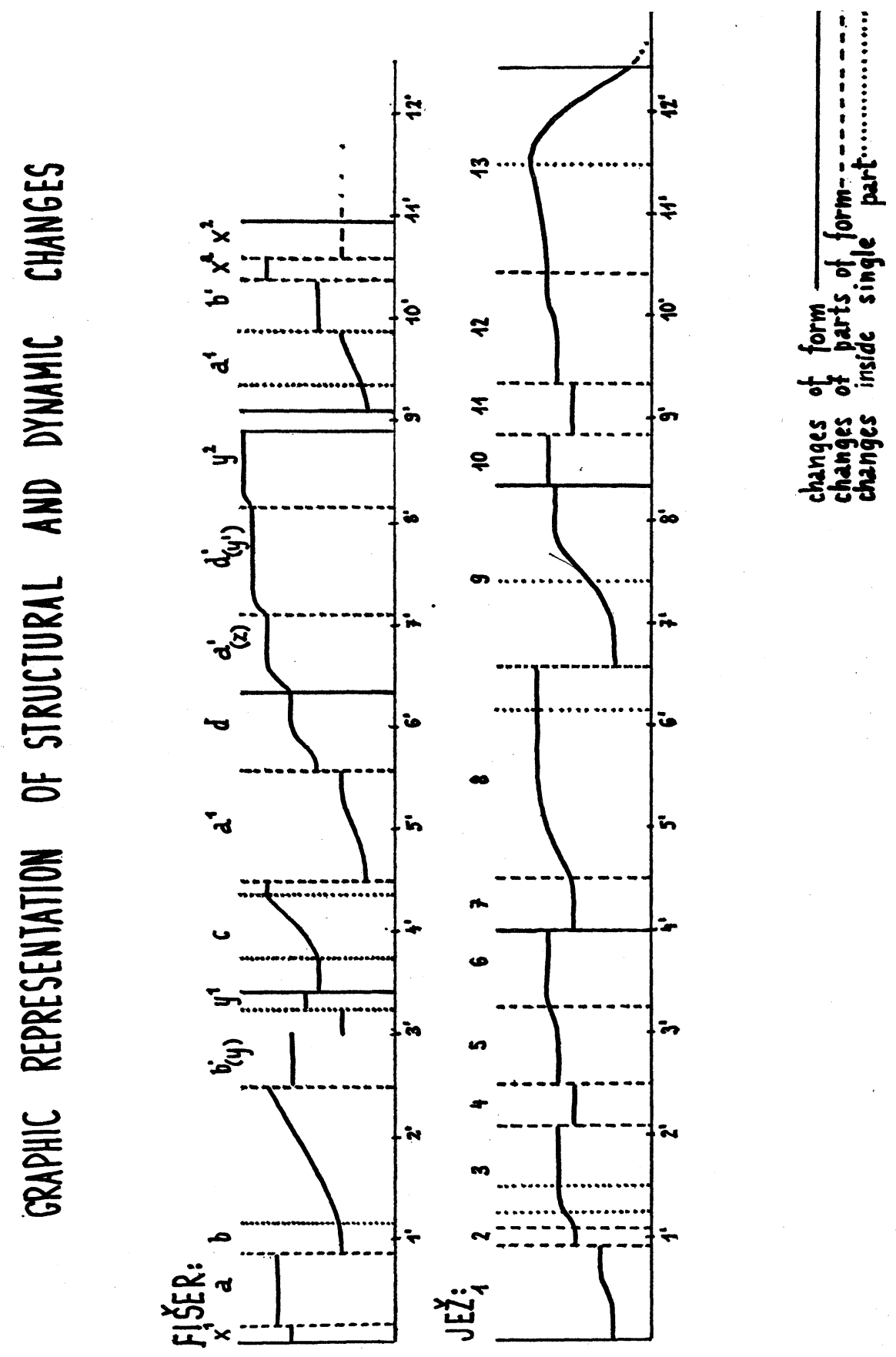


the contraposition: tú $-\mathrm{a}-\mathrm{p} \times \mathrm{p}-\mathrm{t}-\mathrm{p}$ ), as well as words (5: dumumi, according to author's transcription - daughter, ša - heart in Sumerian; 8: chacmool - jaguar, muan - owl in Mayan; 13: ululi - field, taptapa - nest in Hittite), etc. Some meaning-forming syllables have the character of minute punctuation signs: for example, ša in part 3 and 6 . The highly variable much ballad-like expressive whole by its sound creates a lyrical-epical impression of a vivacious narrative of the scene; this corresponds also with the original content of the form "caccia" as a vocal-instrumental form of the Ars nova. Like in other vocal compositions (such as the chorus Stric), the composer engages the elements of theatre into the vocal expression.

Even if it seems that the relation between L. Fišer's and J. Jež's compositions is indirect, it may be assumed that the interest in the ancient languages, or their texts, was induced by similar causes. This is in agreement also with the resulting message of the two compositions and with the intention of the authors. In the Czech and Slovenian Neue Musik this is not the only case of this kind. Let us remember, as far as thematic relations are concerned, at least J. Jež's composition inspired by Jacob Gallus and the electronic motet of Zdeněk Lukáš (born in 1928) on the motet of Jacob Gallus "Ecce quomodo moritur justus" from 1968.

\section{POVZETEK}

Analitična študija podaja primerjavo dveh del »nove glasbe«, po enega češkega in slovenskega, $\mathrm{v}$ jezikih davnih kultur: Žalostinke ob uničenju mesta Ur Luboša Fišerja in kompozicije Caccia barbara Jakoba Ježa. Ob tem pokaže avtorica razlike $\mathrm{v}$ kompozicijski tehniki. Pri Fišerju gre za sintezo modalne tehnike in aleatorike $s$ tematičnim delom, pri Ježu pa za izkoriščanje linearnosti ritmično-melodičnih vzorcev $v$ zaprti strukturi oblike in za sintezo vokalne zvrsti s scenskimi elementi. Vendar so opazne tudi skupne značilnosti: izredna ekspresivnost in močna kontrastnost, zanimanje za tekst in jezike starodavnih kultur/in končno sporočilo obeh del aktualizacija preteklosti. Kompoziciji sta tudi grafično predstavljeni. 